Korzh N., Onyshchuk $\mathbf{N}$.

\title{
SELECTION OF THE OPTIMAL SET OF REVENUE MANAGEMENT TOOLS IN HOTELS
}

Охарактеризовані основні економічні та аналітичні інструменти управління доходами в готелях. Приведені переваги та недоліки основних аналітичних інструментів: Rate Shopper; аналітика та інструментарій в OTA; RMS (revепие management system) - системи управління доходом. Доведена необхідність використання сучасних аналітичних інструментів для оптимізації доходів в готелі та прийняття стратегічних рішень. Для вибору оптимального набору інструментів розроблено процедуру прийняття рішення щодо роботи з аналітичним інструментом.

Ключові слова: revenuе тапаgетепt, оптимізація доходів, аналітичні інструменти, дохід з гостя, дохід з номера, канали продаж.

\section{Introduction}

The era when the hotel's performance was counted by the number of sold rooms, is a thing of the past. The main difference from previous methods of managing the performance of hotel activities is that managers operate with such complex indicator as the profit ratio, reflects the effectiveness of the business activity of the hotel. In this case, the calculation does not take prices as such. Rather, it is about the optimal selection of various segments of consumers, the relationship with which they promise to give the maximum result, which is expressed in the amount of received income. Where earlier the determining factors were the number of overnight stays (sold numbers) and the average price for the sold number, today the coefficients of income are calculated and fluctuations of its volumes are analyzed within the framework of a separate hotel company.

Tactical weapons in the struggle to maintain a market share, increase profitability, or at least the survival of an enterprise in a competitive environment, is the massive use of tools.

Considering the above, it is timely to study modern management tools of Revenue and the possibility of their application in hotels of Ukraine.

\section{The object of research and its technological audit}

The object of research is the scientific category «revenue management» and its tools, which, with the growth of the number of on-line sales channels of hotel services, become decisive in the struggle for survival. The scientific category «revenue management» has been considered for more than fifty years from various angles - an optimization model, an economical technique, additions to SCM, an approach to maximizing income, a tactical approach, a pricing technique, economic principles of revenue management, etc. Accordingly, revenue management is closely related to forecasting, pricing and the use of tactics. The active involvement of information technology in revenue management complicates the process of interpreting this term and needs to be clarified. The choice of the hotel's strategy as the main one becomes more complicated: it focuses on high loading, orientation towards a high average price or orientation to a high index of the level of income per room.

Today, there are a large number of tools that provide analytical information. All of them carry a different function, volume of information and are responsible for a certain aspect of the work. It is important to understand what part of the work it performs, where its place in the entire operational cycle. Therefore, the choice of the source of information is also a big problem in the operating cycle of the hotel. The main discussion point remains the possibility of obtaining large data for making managerial decisions on the tactical movement of the hotel using analytical tools.

\section{The aim and objectives of research}

The aim of research is review of modern tools for managing income in hotels and forming on their basis a sequence of actions to make decisions on their optimization.

To achieve this aim, it is necessary to solve the following tasks:

1. To clarify the concept and essence of revenue management.

2. To analyze the advantages and disadvantages of analytical tools and prove the need for their use in the development of strategic decisions.

3. To develop a procedure for making managerial decisions to optimize the set of analytical tools.

\section{Research of existing solutions of the problem}

The scientific interest in revenue management emerged in the late 1970 s in airlines and is now widely used today not only by large companies, but also by small businesses. In general, such definitions of revenue management are common in the literature:

- real-time pricing - an optimization model based on demand forecasting [1, 2]; 
- an economical technique for optimizing the income of a hotel based on the conformity of the price policy to the behavior of demand [3, 4];

- an addition to SCM, which addresses supply decisions and company processes, with a view to (as a rule) reducing the cost of production and delivery [5]; - the way information data and pricing strategies are used to implement the correct volumes of products to the right consumer at the right place at the right time [6]; - a systematic approach to maximize revenue from the sale of numbers by manipulating tariffs in accordance with predicted changes in the structure of demand [7, 8]; - application of tactical approaches for predicting consumer behavior at the micro-level level and optimizing the availability and price of products in order to maximize revenue growth $[9,10]$.

Many studies determine that revenue management provides for the three main categories of demand management solutions, structural, price and quantity. But the priority of these decisions is determined in the context of each region in different ways. For example, in [3], revenue management is divided into two theories: quantitative-price in the distribution of potential and pricing. Both theories of revenue management depend on which control variable is used, and therefore use this dichotomy as necessary.

\section{Methods of research}

The material of the research is based on observations and personal experience of the author, analysis of the existing on the market software complexes of analytical data influencing the decision making about tactical actions of the hotel in the markets. This information is rather scattered and requires generalization.

To solve the research problems, the method of theoretical generalizations and the method of comparison were used.

\section{Research results}

Depending on their specific nature, incomes realized by tourism enterprises can be divided into three large groups: income from core business; financial income; income from other events.

Income from core business, as a rule, prevails in the total income for the reporting period. Depending on the specific nature of the activity, it is possible to determine the specific composition of income from the main activity. The effectiveness of revenue management is based on an analysis of the factors that affect their level. Direct factors include: sales volume; the selling price, as well as the sales structure. To indirect it is necessary to carry: quality of services or the goods, marketing and a price policy, advertising, management, changes of material base, hotel capacities, kinds of additional services market factors.

The main task of managing hotel revenues is analysis of two key factors:

- bed prices (price factor);

- occupancy of the hotel base (quantity factor).

The main source of information on income management is their analysis. Practically revenue management begins with an analysis of the results achieved to a suitable moment, the determination of the development trends of the enterprise by comparing it with previous years or with an average level in the region for the corresponding period.
Efficiency of income management is provided by passing through the following stages:

1. Analysis of the structure of income by type of sales.

2. Analysis of revenues by source types (costs and revenues are compared by type of activity in order to determine the effectiveness of each of them).

3. Analysis of factors such as the number of sales and sales price of revenue by source with the aim of optimizing them.

4. Determination of the optimal level of occupancy of the hotel base at the optimal price levels.

5. Evaluation of the achieved results.

In order to plan the sale policy, and then evaluate the result in hotels, use the economic tool - the main hotel indicators:

- the average tariff (ADR);

- the average income per number (RevPAR);

- the average number of hotel per room (DOUBLE OCCUPANCY);

- the average income for 1 guest per day/month/ year (RevPAC - revenue per available Customer).

They are calculated without VAT and the cost of food. These indicators are analyzed in dynamics and compared with competitors to understand the development trend of the hotel and its positioning in a competitive environment. And if revenue and congestion are direct indicators, then in other indicators there is a certain process.

Let's start with the average selling price. In practice, the hotel does not implement rooms at the rates announced at the reception. There are always contracts, special offers, rises and a decrease in demand. For this it is necessary to react in a certain way. In fact, ADR is the price minus 10-15\% of the average price at the desk (ReCrate). In suburban hotels and regions this is $12-15 \%$, in megacities - $20 \%$ [2].

The following factors affect ADR:

- competitive environment (can't be sold at the desired price);

- seasonality (dynamic pricing);

- the hotel's response to the demand and elasticity of the holiday tariff;

- inflation.

RevPAR is average income per number is not independent (direct), but a derived indicator that depends on the level of loading and the average selling price, that is, it can vary depending on the variation of these derivatives. This is an indicator that, combined with the dynamics of the load indicator, indicates the effectiveness of the tariff policy applied by the hotel. In other words, RevPAR is an indicator that measures the effectiveness of a combination:

$$
\% \text { of occupancy - average price (ADR). }
$$

RevPAR $=$ the proceeds from the sale of the room fund/the number of all available rooms in the occupancy factor.

That is, RevPAR can be obtained by a small occupancy, but at a high price or with a large occupancy, but cheap. It is measured in hryvnia, and is calculated without taking into account the amount of taxes and food.

This indicator is used for:

- investors when choosing investment decisions (the dynamics of the indicator shows the feasibility of investment); 
- internal analysis of the hotel development (the dynamics should be positive) [10].

The hotel, calculating this indicator will be able to analyze the performance of its activities on a monthly basis. Comparing the figures of RevPAR, the hotel management can give an assessment of the marketing policy conducted: is it correctly chosen and does not require an adjustment? Indeed, the analysis of the occupancy and average prices of direct competitors in the market is the most effective way of comparing the performance of individual sectors of the market and their place in relation to them. Competitive hotels that conduct different marketing policies may have the same RevPAR, while occupancy and average prices will vary significantly. Thus, RevPAR serves as a valuation tool, and not a commercial method. It provides an opportunity to carry out work to optimize the efforts that contribute to the improvement of the hotel.

DOUBLE OCCUPANCY (DO) - the average number of hotels per room is an important indicator when positioning the hotel. When it comes to purchasing a hotel or taking it to the management, when planning a budget, it's always estimated the positioning. It determines the number of people per room and the length of stay. Modern hotels aim to expand the range of services to increase income. So the city business hotel will be equipped with fitness services, SPA. Country hotels will complement the range of conference services, wellness programs, etc.

RevPAC - revenue per available Customer - the average income for 1 guest per day/month/year. It flows smoothly from RevPAR.

RevPAC $=$ Gross income/number of guests who lived in this period.

RevPAC characterizes the professionalism of sales managers - how skillfully they realize the services of the hotel, the higher this indicator. The bonus for them is paid depending on the fulfillment of the plan from RevPAC (income per guest) [11].

Thus, the sales cycle can be reduced to the following stages:

1. Determine the timing of the task and indicators. The criteria will be: revenue, ADR, occupancy, RevPAR, RevPAC and the average number of guests.

2. Determine the priority client segments and sales channels that will be most effective for working with this segment (based on experience and plan).

3. Develop a motivation program for this client segment and hotel staff. Form a media plan for this period.

4. With the passage of time, the planned indicators are compared with those achieved, analyze the errors, and put additional possibilities.

The hotel manager always has a budget to fulfill. But there are cases when there is a backlog from the plan. This shows that it is necessary to sell the policy not only for a month, a week, but every day. This will allow the manager to understand how to work tomorrow to finally fulfill the budget for the hotel and adjust the flows.

Thus, the hotel efficiency is assessed according to two criteria:

1. Implementation of plans and budgets.

2. Achievement of results (tariffs, prices, loading, market share) in comparison with competitors [12].
Obviously, without an evaluation of the results of the work compared to competitors, one can't say with certainty about the efficiency of the hotel and the income management system. In particular, without the market data, it is impossible to correctly assess the result: «The hotel did not fulfill the plan through good work, but because of the high demand in the market?» Or vice versa «Perhaps the decline in hotel performance was not as significant as the market in general and the results of the hotel proved to be much better than those of competitors».

All the methods discussed above find their practical application in the revenue management system. Monitoring and analysis of these systems are carried out by using certain techniques and will allow managers to manage the results and provide for them. The main types of analysis are: models of customer behavior; dynamics of results; optimization of results, threshold curves [12].

For analysis, it is necessary a large data set. The concept of «data» is divided into two groups: BigData (this is information about what surrounds the hotel business) and SmallData (this is information that is in the hotel system or the sales channel manager). This is not just a discrimination of data - it's a software package, a toolkit that allows to work with specific information. All data can be divided into structured (for example, reservation information) and not structured (for example, customer reviews that are difficult to analyze). Analytical tools allow to combine these types of data, facilitating the transition from the amount of information to a quality manager accessible to competent work.

When working with data, there must be an understanding that the existence of a toolkit that combines information about demand in the market and predicts events, exchange rates, etc., has a qualitative increase in the occupancy of the hotel. And this is not BigData it's working with different SmallDat. Now there are many types of analytical tools that work differently with this or that data. Their analysis allows the following classification:

- descriptive analytics (uses large groups of data to

describe what is happening in the market and provides recommendations);

- predictive analytics (uses large groups of data to predict events on the market);

- perspective analytics (uses large groups of data to provide recommendations and forecasts).

But there is no perspective analyst in full in one of the existing instruments today - one submits information on the ratings, the other on the fluctuations in demand or tariffs. It combines all information with a promising analyst, for which the future.

The main analytical tools of revenue management can be classified into:

- tools for optimizing sales;

- for sales control.

These include: Rate Shopper; analytics and tools in OTA; Business Intelligence (BI) tools; RMS (revenue management system) - income management systems; forecasting tools; tools of market analysts (benchmarking) tools for distribution and management of sales channels, etc. Let's consider the advantages and disadvantages of these basic tools.

OTA (booking, expedia) performs the following tasks: provides statistics on the sales channel; dorms an analysis of future trends and results through the sales channel; estimates the results of sales at the hotel and compares 
them with competitors, but within the channel. At the same time, this tool does not give an objective forecast for the market, only through the channel and does not give recommendations on the sale of numbers, only points to certain changes in the market and among competitors. Once again, let's emphasize that this tool shows the results of sales in comparison with competitors only within the channel, not as a whole in the hotel. This tool is free.

Rate shopper compares and controls the prices of the hotel and competitors in open sources and sales channels (GDS depending on the product, category of rooms, tariff policy - depending on the product). That is, it allows to see the open prices of hotels and analyze the sale policy for specific dates. In addition, this tool tracks changes in the policy of sales of competing hotels for future periods and compares it with the rates of this hotel to support the decision-making process on open public tariffs. Checks compliance with parity, as well as closed dates on channels (but not for all products), detects sites that violate parity. Rate shopper is a paid tool and does not give recommendations on tariffs.

RMS (revenue management system). The main tasks of the tool are as follows:

- forecast calculation (ADR, RevPAR, occupancy, income by hotel or segments);

- daily recommendations on tactical actions;

- a general palette of sales (in-

cluding rate shopper, analytics, statistics).

The disadvantage is that the system does not allow to evaluate the effectiveness and correctness of the actions and recommendations provided by the tool, the reporting modules do not provide instructions for actions taking into account the results of analysis for large dates, only visualization.

Analysis of companies that provide different information to hotel managers allowed them to be grouped as follows (Table 1).

Grouping of companies that provide information for hotels by main categories of analytical data

\begin{tabular}{|l|l|}
\hline Category of analytics & \multicolumn{1}{|c|}{ Name of companies providing analytics } \\
\hline RMS & $\begin{array}{l}\text { Booking Suite, Rate Checker, HQ Plus, Travelline, } \\
\text { Rate Tiger, Rate Gain, Rate Mate, Ota insight, Sit } \\
\text { minder and other }\end{array}$ \\
\hline Market analytics & $\begin{array}{l}\text { HotelAdvisors, STR, Fairmas,Benchmarking Alli- } \\
\text { ance, HotStats, MKG Group, HotelBench and other }\end{array}$ \\
\hline BI (business analytics) & $\begin{array}{l}\text { Snashot, HotelsBI, Xotels, Morse, Hotel lab and } \\
\text { other }\end{array}$ \\
\hline
\end{tabular}

Note: compiled by the author.

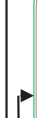
competitors loading (pick un)

Criteria:

Table 1
Each hotel chooses at its discretion, with which analytical tools to work. All instruments carry a different function and amount of information and are responsible for a certain aspect of the work. Therefore, with all this tools, it is definitely need to work. It is important to understand what part of the work it performs, where its place in the entire operational cycle.

In order to understand how the process of decisionmaking on the work with the tool is moving, what place is occupied by this or that tool, what information it allows to provide, a diagram is drawn up in Fig. 1.

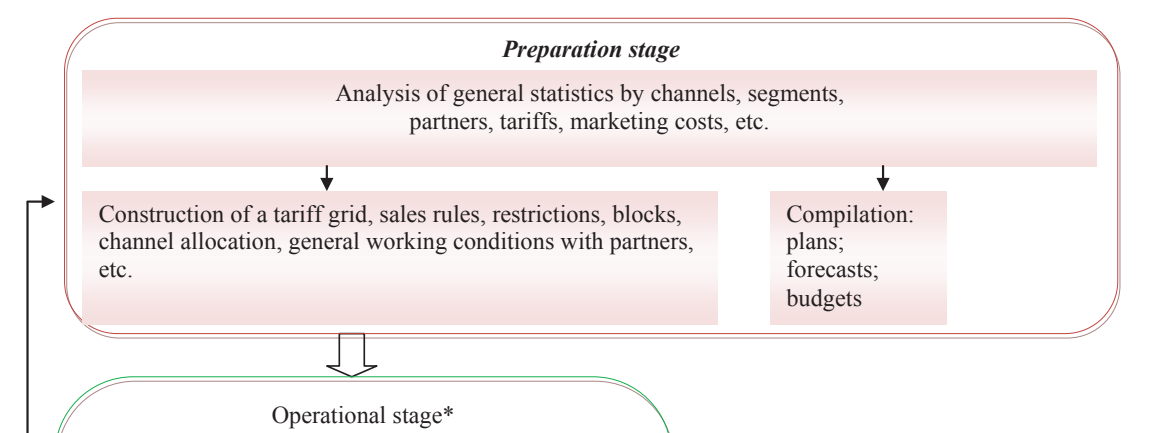
PMS+BI: statistics for previous periods and by segments Rate Shopper - information on open tariffs for numbers from

OTA analytics: information on market dynamics and demand in the context of sales channels

BI or PMS analytics information on the pace of booking (pace) wd loding (pick up) Analytics VI or PMS: information on the pace of booking (pace) and

RMS: recommendations and forecast

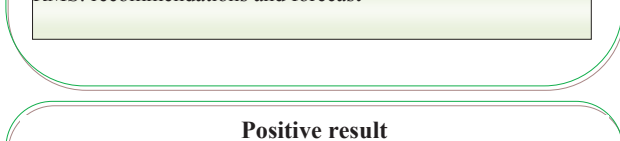

1) the budget is executed in comparison with last year's progress, market indices $>100 \%$

2) price index (API) and loading index $(M P I)<10 \%$

forecasted market share $>$ actual It is possible to transfer practice to similar periods

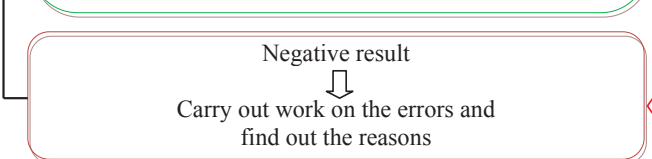

Fig. 1. The decision-making model for the optimal set of analytical tools for forecasting (compiled by the author): *for each hotel, the set of tools can be different

The decision-making process begins at the preparatory stage, during which the analysis of statistics, sales by channels, segments, partners, etc. is conducted. As a result of this analysis, the manager creates tariff grids, sales rules, restrictions, working conditions with partners and draws up a plan, forecasts, sales budgets. This process is carried out at the end of the year and is adjusted during the next period, depending on the changes.

Next, an operational process takes place, within which tools are directly used (within the information that is interesting to the hotel), which are usually available to the hotel (that is, with whom the transactions are concluded). There is no tool that in the complex would provide all the information from the market for the hotel. Therefore, 
there is a need to use several tools to own information about the market.

As a result, the manager receives a large amount of information that allows to make a decision about the further actions of the hotel in certain sales channels (direct booking, electronic channels, corporations, agencies, group sales).

After all are implemented, the result of the hotel's performance is estimated, which is compared with its budget, forecast, past period and, of course, with the market. The result can be positive or negative. If obtain a positive result, it is possible to continue a work in the operating unit. If a negative result is obtained (the reverse of the positive result), it is necessary to find out the errors and therefore it should return to the preparatory stage.

This is where need to look for the cause of the error, find out where the false information was received, which led to a negative result.

Thus, this scheme shows that all the tools are different, each of them has a specific function and is responsible for the specific amount of information and the amount of work.

\section{SWOT analysis of research results}

Strengths. The strength of research is the structuring of an array of analytical tools on information that can be used in the hotel's operating activities, as well as the development of a decision-making scheme for the optimal set of analytical tools for forecasting.

Weaknesses. The weak side is that the number of analytical tools is growing, and there is no single tool with perspective analytics.

Opportunities. Opportunities for further research are the development of prospective analytics.

Threats. The threat to the introduction of analytical tools for revenue management in hotels in Ukraine is the inertia of owners and the reluctance to learn modern technologies for data collection and analytics, the approach to the site as a virtual office. The use of profit management tools will require additional costs for the training of personnel, expansion of sales channels and modernization of technical resources.

\section{Conclusions}

1. The need for effective management of the information resource for its correct and timely processing, systematization and use in modern Ukrainian realities is the main task of making effective management decisions. In the course of the study, there were a combination of modern possibilities of the tools of revenue management and information that will allow to form a new approach to decision making that has profound consequences for demand management:

- the ability to manage demand in terms of scale and complexity, which would not be possible by manual means;

- the possibility of improving the quality of solutions for managing demand under uncertainty;

- flexible pricing economy;

- accurate interpretation of market conditions and trends and timely, accurate and consistent responses to this information in real time;

- optimization of the complex of the objective function, subject to many restrictions and business rules.
Taking into account the above aspects, forming conditions for the introduction of revenue management, it should be perceived as an auxiliary method of maximizing profits from a fixed perishable resource based on understanding, forecasting and strategic influence on consumer behavior.

2. The advantages and disadvantages of the analytical tools common in the country are analyzed: Rate Shopper; OTA; BI and RMS. The main analytical tool for revenue management is classified into: sales optimization tools and sales monitoring tools. That is, each tool provides a specific array of information that is either descriptive or provides predictive analytics. It is proved that no tool provides perspective analysis and therefore it is necessary to use several tools. Since this is an economic issue, the hotel must have an optimal set of such tools for the development of strategic decisions.

3. A model for making managerial decisions to optimize a set of analytical tools is proposed. This model demonstrates how the decision-making process for working with the tool should move. According to the model, each hotel can, at its discretion, select a set of analytical tools and check their relevance to the operational cycle of the hotel and informative for the development of strategic decisions.

\section{References}

1. Kozlov D. A. Yield Management in Hotels. CreateSpace, 2014. $234 \mathrm{p}$.

2. Josephi S. H. G., Stierand M. B., Van Mourik A. Hotel revenue management: Then, now and tomorrow // Journal of Revenue and Pricing Management. 2016. Vol. 15, No. 3-4. P. 252-257.

3. Talluri K., van Ryzin G. The Theory and Practice of Revenue Management. Boston: Springer, 2005. 731 p. doi:10.1007/b139000

4. Revenue Management: Progress, Challenges, and Research Prospects / Wang X. L. et al. // Journal of Travel \& Tourism Marketing. 2015. Vol. 32, No. 7. P. 797-811. doi:10.1080/ 10548408.2015.1063798

5. Phillips R. Pricing and Revenue Optimization. Stanford University Press, 2005. 364 p.

6. Kimes S. E. Revenue management on the links: Applying yield management to the golf industry // Cornell Hotel and Restaurant Administration Quarterly. 2000. Vol. 41, No. 1. P. 120-127. doi:10.1177/001088040004100129

7. Jauncey S., Mitchell I., Slamet P. The meaning and management of yield in hotels // International Journal of Contemporary Hospitality Management. 1995. Vol. 7, No. 4. P. 23-26. doi:10.1108/09596119510083229

8. Jones P. Yield management in UK hotels: a systems analysis // Journal of the Operational Research Society. 1999. Vol. 50, No. 11. P. 1111-1119. doi:10.1057/palgrave.jors.2600739

9. Cross R. G. Launching the revenue rocket: How revenue management can work for your business // Cornell Hotel and Restaurant Administration Quarterly. 1997. Vol. 38. No. 2. P. 32-43. doi:10.1177/001088049703800222

10. Ferguson M., Smith S. The changing landscape of hotel revenue management and the role of the hotel revenue manager // Journal of Revenue and Pricing Management. 2014. Vol. 13, No. 3. P. 224-232. doi:10.1057/rpm.2014.11

11. Korzh N. V. Theoretical basis and praxeology revenue management // Scientific letters of international academic society of Michal Baludansky. 2017. Vol. 1. P. 131-136.

12. Skugge G. Growing effective revenue managers // Journal of Revenue and Pricing Management. 2004. Vol. 3, No. 1. P. 49-61. doi:10.1057/palgrave.rpm.5170093 


\section{ПОДБОР ОПТИМАЛЬНОГО НАБОРА ИНСТРУМЕНТОВ REVENUЕ МЕНЕДЖМЕНТА В ГОСТИНИЦАХ}

Охарактеризованы основные экономические и аналитиче ские инструменты управления доходами в гостиницах. Приведены преимущества и недостатки основных аналитических инструментов: Rate Shopper; аналитика и инструментарий в OTA; RMS (revenue management system) - системы управления доходом. Доказана необходимость использования современных аналитических инструментов для оптимизации доходов в отеле и принятия стратегических решений. Для выбора оптимального набора инструментов разработана процедура принятия решений по работе с аналитическим инструментом. ключевые слова: revenue management, оптимизация доходов, аналитические инструменты, доход с гостя, доход с номера каналы продаж.

Korzh Nataliia, Doctor of Economic Science, Professor, Depart ment of Management and Administration, Vinnytsia Institute of Trade and Economics of the Kyiv National University of Trade and Economics, Ukraine, e-mail: norischuk067@gmail.com, ORCID http://orcid.org/0000-0002-4901-3078

Onyshchuk Natalia, PhD, Senior Lecturer, Department of Tourism and Hotel and Restaurant Business, Vinnytsia Institute of Trade and Economics of the Kyiv National University of Trade and Economics, Ukraine, e-mail: onivin@ukr.net, ORCID: https:// orcid.org/0000-0002-2513-2259
Plikus I.

INVESTIGATION OF THE EXISTING
METHODOLOGY OF VALUE ESTIMATION
AND METHODS OF DISCOUNT RATE
ESTIMATION

Розкрито економічна сутність справедливої й теперішньої (дисконтованої) вартості та досліджено їх використання у Міжнародних стандартах фінансової звітності. Запропоновано алгоритм вибору методів оцінки за справедливою вартістю з використанням дисконтування. Проаналізовано існуючі підходи до оцінки ставки дисконтування та запропоновано формули розрахунку ставки дисконтування для обгрунтованого відображення в обліковій політищі підприємства.

Ключові слова: алгоритм вибору методів оцінки за справедливою вартістю, оцінка ставки дисконтування, розрахунок ставки дисконтування.

\section{Introduction}

In the globalization and integration processes, accounting and financial reporting play a fundamental role in providing operational, tactical and strategic information management, so ensuring its reliability and reliability becomes a top priority. However, accounting systems in which elements of financial statements are valued only at historical cost, do not fully meet the needs of the business. In this regard, the priority direction for development of the valuation of assets and liabilities of enterprises is the concept of fair value, since this estimate better reflects the actual value of assets and liabilities. It should be noted that in the international practice this assessment is sufficiently integrated, confirming its advantages, but at the same time there are difficulties in its understanding, namely, the determination of fair value by the method of current (discounted) cost and the choice of the discount rate. The importance of this issue is underscored by the 9th meeting of the Developing Council Group on International Financial Reporting Standards (IFRS), which was held on May 25-26, 2015 in Mexico City, and was devoted to the application of the present (discounted) cost in selected IFRSs and the choice of discount rates in the member countries of the Group [1].

\section{The object of research and its technological audit}

The object of research is the current practice of determining the fair value of assets and liabilities using discounting. According to International Financial Reporting Standards, discounting is an integral part of accounting. This process can affect the carrying amount of any asset or liability, the financial performance of the entity during the reporting period and the reliability level of the financial statements. The process of discounting is not difficult. One of the most problematic places is the determination of the discount rate, which belongs to the jurisdiction of a professional accountant's judgment.

\section{The aim and objectives of research}

The aim of research is substantiation of the choice of the method of estimating the discount rate in order to increase the reliability level of financial reporting.

To achieve the stated aim, it is necessary to determine the following tasks:

1. To propose an algorithm for choosing methods for fair value estimation. 